\title{
Changes of intestinal epithelial structure and cell turnover in carp Cyprinus carpio infected with Goussia carpelli (Protozoa: Apicomplexa)
}

\author{
Nicole Hemmer ${ }^{1}$, Dieter Steinhagen ${ }^{1, *}$, Wolfgang Drommer ${ }^{2}$, Wolfgang Körting ${ }^{1}$ \\ ${ }^{1}$ Fish Disease Research Unit, School of Veterinary Medicine, Bünteweg 17, D-30559 Hannover, Germany \\ ${ }^{2}$ Pathology Department, School of Veterinary Medicine, Bünteweg 17, D-30559 Hannover, Germany
}

\begin{abstract}
Epithelial cell turnover in the intestine of common carp Cyprinus carpio infected with the coccidian parasite Goussia carpelli (Leger \& Stankovitch, 1921) was investigated during laboratory infection using histological and electron microscopical techniques. During the development of the parasite an increased number of mitotic enterocytes, identified by bromodeoxyuridine (BRDU) uptake, were observed at the base of infected mucosal folds. During the merogonic and gamogonic development of the parasite, severe damage to infected epithelium occurred, and concomitantly BRDU-positive cells spread along the mucosal folds. These cells exhibited immature characteristics, including a squamous to cuboidal shape, nuclear apolarity, a high number of ribosomes, and short or reduced microvilli. Contact with adjoining cells was formed by tight junctions and desmosomes, indicating the epithelial origin of these cells. These cells covered gut segments with damaged epithelium within a few days, suggesting a high regenerative capacity of the carp intestine, and this could explain the mild clinical symptoms in fish affected by $G$. carpelli-coccidiosis. Our study for the first time describes epithelial cell responses to injuries caused by enteric protozoa in piscine hosts.
\end{abstract}

KEY WORDS: Carp coccidiosis - Epithelial cell turnover - Enteric infection - Tissue repair - Goussia carpelli Cyprinus carpio

\section{INTRODUCTION}

Goussia carpelli Léger \& Stankovitch, 1921 causes enteric coccidiosis, a serious disease in hatchery populations of common and ornamental carp Cyprinus carpio L. and of goldfish Carassius auratus in Europe and North America (Schäperclaus 1979, Kent \& Hedrick 1985). The parasite infects juvenile fish by fecal contamination and by indirect transmission via tubificid oligochaetes (Steinhagen \& Körting 1990). The parasite develops sequentially in enterocytes along the entire intestine, similar to the development process seen in homoiothermic vertebrates. Development includes asexual proliferation (merogony), gamogony, fertilization, and formation of oocysts, which sporulate in situ and are excreted with the feces (Lom et al. 1991, Steinhagen 1991, Davies \& Ball 1993).

\footnotetext{
- Addressee for correspondence.

E-mail: dstein@fisch.tiho-hannover.de
}

The pathogenicity of Goussia carpelli remains unclear: fish breeders and fish pathologists report high mortalities in juveniles and fry fish. In laboratory experiments, infected carp suffer from ion Ioss, decreased osmolarity and protein contents of the blood plasma, and were more susceptible to invasion by opportunistic bacteria (Steinhagen et al. 1997). The sequential histopathology was described by Jendrysek et al. (1994). In their observations, severe losses of intestinal epithelium, destruction of the intestinal architecture, and leucocytic infiltration of lamina propria were found (Lom \& Dykova 1992, Jendrysek et al. 1994). In severely affected tissues, enterocytes were destroyed and the lamina propria was covered by broad, squamous epithelium-like cells (Jendrysek et al. 1994). The present study was undertaken to further investigate the origin and the structure of these cells and their relationship to the regeneration process of pathogen-induced lesions in the intestinal tract of fishes. 


\section{MATERIALS AND METHODS}

Fish. In this study carp Cyprinus carpio L. of a single crossing (E20 $\times$ R8, Wageningen Agricultural University, Wageningen, The Netherlands) were raised from fertilized eggs in coccidia-free conditions in our laboratory in aerated tap water at $20 \pm 2^{\circ} \mathrm{C}$ and fed commercial fish feed (Trouvit, Trouw \& Co., Putten, The Netherlands).

Infection experiments. For infection experiments, carp (10 wk old, weighing 1 to $3 \mathrm{~g}$ ) were used. To induce an infection with Goussia carpelli, fish were placed into an $80 \mathrm{l}$ tank with water containing 10000 oocysts, held for $24 \mathrm{~h}$, and then transferred to tanks with clean water at 20 to $24^{\circ} \mathrm{C}$. For controls, uninfected carp were kept under identical conditions. On Days 2, 4 to 13, and 18 post-exposure (PE) to oocysts, gut material from 3 or 4 infected and uninfected carp were sampled and processed for light and electron microscopical examination. To detect mitotic activity in enterocytes, $5 \mathrm{~h}$ prior to tissue sampling, carp were intraperitoneally injected with 5-bromodeoxyuridine (BRDU, Sigma, St. Louis, MO, USA) at $250 \mathrm{mg} \mathrm{kg} \mathrm{kg}^{-1}$ body weight in sterile phosphate-buffered saline [PBS, $0.85 \%$ (w/v), pH 7.2].

Tissue samples. Carp were chilled on ice, killed by severing the spinal cord caudal to the brain case, necropsied, and the gut was removed. For BRDU detection, 2-4 $\mathrm{mm}^{3}$ pieces of gut tissue were placed into phosphate-buffered $4 \%$ paraformaldehyde solution ( $\mathrm{pH} 7.2$ ) overnight, dehydrated in a graded series of ethanols, embedded in paraffin wax and sectioned at $4 \mu \mathrm{m}$ thickness. Sections were processed for immunocytochemistry (see below) to detect incorporated BRDU and stained according to Giemsa's method (Romeis 1968). For electron microscopy, small pieces of intestinal tissue were removed and fixed in $2.5 \%$ glutaraldehyde dissolved in $0.1 \mathrm{M}$ cacodylate buffer ( $\mathrm{pH} 7.2$ ), postfixed with $1 \%$ osmium tetroxide in the same buffer, dehydrated in a series of graded ethanols and, after infiltration via propylene oxide, were embedded in epon. Thin sections were stained with uranyl acetate and lead citrate, and observed with a Zeiss EM 10 electron microscope.

Immunocytochemistry. The detection of BRDU incorporation followed standard protocols (Schutte et al. 1987). Deparaffinised and rehydrated tissue sections were placed in $0.3 \% \mathrm{H}_{2} \mathrm{O}_{2}$ to block endogenous peroxidase activity. Thereafter, cells were denatured with $2 \mathrm{~N} \mathrm{HCl}\left(30 \mathrm{~min}\right.$ at $\left.37^{\circ} \mathrm{C}\right)$. The reaction was stopped by incubation of sections in $0.1 \mathrm{M}$ sodium tetraborate (pH 8.5). Then the sections were washed with $0.05 \mathrm{M}$ Tris-buffered 0.15 M PBS. Incorporated BRDU was labelled by successively incubating the sections in anti-BRDU monoclonal antibody (diluted 1:50 in Trisbuffered $0.5 \mathrm{MPBS}, 1 \mathrm{~h}$ at 20 to $24^{\circ} \mathrm{C}$ ), biotinylated rabbit anti-mouse antibodies 1 1:50 in the same buffer, $1 \mathrm{~h}$ room temperature) and peroxidase conjugated streptavidin $11: 200$ in the same buffer, $30 \mathrm{~min}$ reagents: Dako Corp., Glostrup, Denmark). Peroxidase activity was determined with diaminobenzidine enhanced with cobalt chloride [0.1\% (w/v), Sigma]. Unlabeled nuclei were counterstained with calcium red.

Preparations were observed with a Zeiss photo microscope, and the number of labeled cells in 10 to 15 mucosal folds were determined; then, the number of labeled cells per mucosal fold was calculated for each preparation. From each fish, gut samples from the 2nd third of the first segment of the intestine were evaluated.

Statistics. The number of proliferating cells per mucosal fold in the gut of infected carp was compared to uninfected controls by nonparametric analysis (Mann-Whitney $U$-test). Differences between groups were considered significant at $p<0.05$.

\section{RESULTS}

\section{Development of the coccidia}

All carp exposed to Goussia carpelli oocysts developed coccidiosis. Merogonic stages were observed from Days 2 to 9 , gamonts on Days 7 and 8 , and oocysts on Days 9 to $18 \mathrm{PE}$.

\section{Epithelial cell turnover and structure}

During development of the parasite, increased epithelial cell turnover occurred in Goussia carpelliinfected carp. On Day $2 \mathrm{PE}$, some merogonic stages were found in enterocytes at the tip of mucosal folds. Mitotic cells, visualized by means of BRDU uptake, were present at the base of mucosal folds (Fig. 1). No difference in number was found between infected and uninfected carp. From Days 4 to 10 and on Day $13 \mathrm{PE}$ the number of infected enterocytes increased rapidly. During this period, a significantly higher number of BRDU-labeled cells were found in the gut of infected carp, as compared to control carp (Figs. 2 \& 6). From BRDU-labeled preparations cell turnover rate was estimated. In uninfected carp, enterocytes had a turnover rate of about $3 \mathrm{~d}$. This decreased to approximately $8 \mathrm{~h}$ on Days 6 and 9 PE. On Day 18 PE parasitized carp had excreted most oocysts, very few oocysts remained in intestinal tissue, and the number of mitotic enterocytes declined to the level of the uninfected controls.

In control carp and on Day 4 PE in infected carp, mitotic cells were seen at the base of mucosal folds. During parasite development on Days 8 to $11 \mathrm{PE}$, 


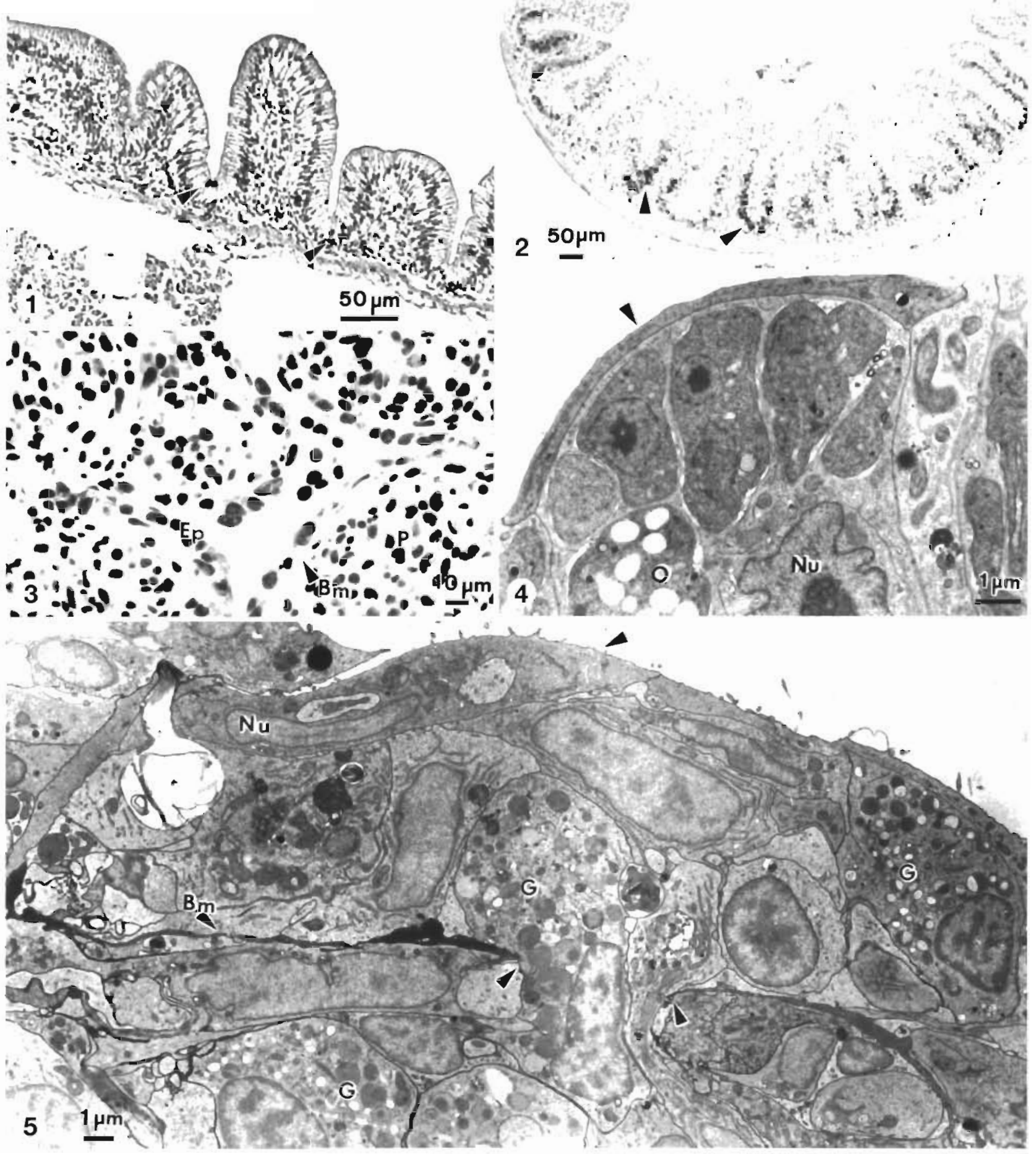

Figs. 1 to 5. Intestinal tissue of common carp Cyprinus carpio infected with Goussia carpelli. Fig. 1. Light micrograph of a cross section of uninfected control tissue. Darkly stained mitotic cells, which are visualized by means of BRDU uptake, are present at the base of mucosal folds (arrowheads). Fig. 2. On Day 8 post-exposure (PE) to the parasite, darkly stained BRDU-labelled cells (arrowheads) were observed at median of the folds. Figs. 3 to 5 . Regeneration of tissue damage caused by a $G$. carpelli infection. Fig. 3. Cross section of infected intestine at Day $8 \mathrm{P} \overline{\mathrm{E}}$. The milicosal folds are covered with a layer of squamous epithelium (Ep). $\mathrm{Bm}$ : basal membrane; P: submucosa. Fig. 4. An undifferentiated squamous cell (arrowhead) covers a heavily infected cell (transmission electron micrograph; O: macrogamont; Nu: nucleus of infected host cell). Fig. 5. Regenerating tissue with an irregular cover of immature epithelium cells, which form some short microvilli (arrowhead). Within the layer of epithelium cells granulocytes $(G)$ are present. A granulocyte is penetrating the basal membrane (Bm, arrowheads) 


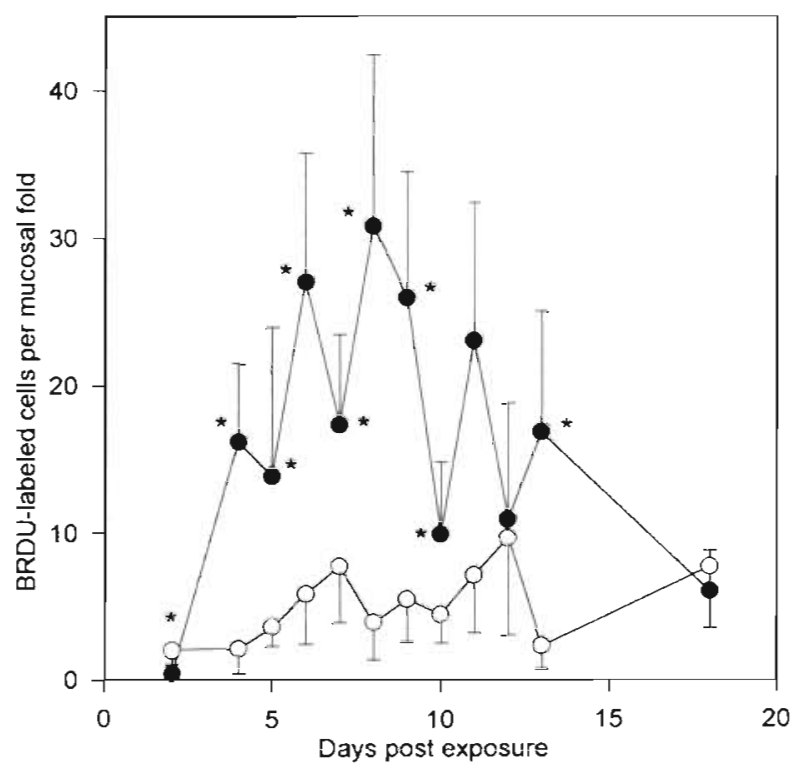

4 Fig. 6. Number of mitotic cells per mucosal fold in the in testines of carp during the course of a Goussia carpelli infection. Depicted are mean \pm standard deviation of measurements from 3 or 4 carp. (-O) Non-infected control carpi (-O) carp with $G$. carpelli infection. Mucosal scrapings of infected carp contained merogonic stages at Days 2 to 8 post-exposure (PE), gamonts at Days 7 and $8 \mathrm{PE}$, and oocysts at Days 9 to $18 \mathrm{PE}$. Significant differences $(\mathrm{p}<0.05)$ between infected and non-infected carp are indicated by asterisks

Figs. 7 to 9. Electron micrographs of immature epithelium cells from the intestine of Goussia carpelli-infected carp. Fig. 7. Undifferentiated cell with a cuboidal shape, central nucleus ( $\mathrm{Nu}$, a few mitochondria (M), numerous ribosomes and a welldeveloped Golgi apparatus (Go). Contact with adjoining cells is formed by desmosomes (arrowhead, boxed area). Fig. 8. Closeup view of Fig. 7, which shows the contacl zone of 2 adjoining immature epithelial cells. This contact is formed by desmosomes ( $\mathrm{D}$; boxed area in Fig. 7 ). In the cytoplasm of the cell, numerous ribosomes (Rib) are present. Fin. 9. Undifferentiated epitheluum cell with irregularly shaped nucleus $(\mathrm{Nu})$ and very few short microvilli. G: granulocyte
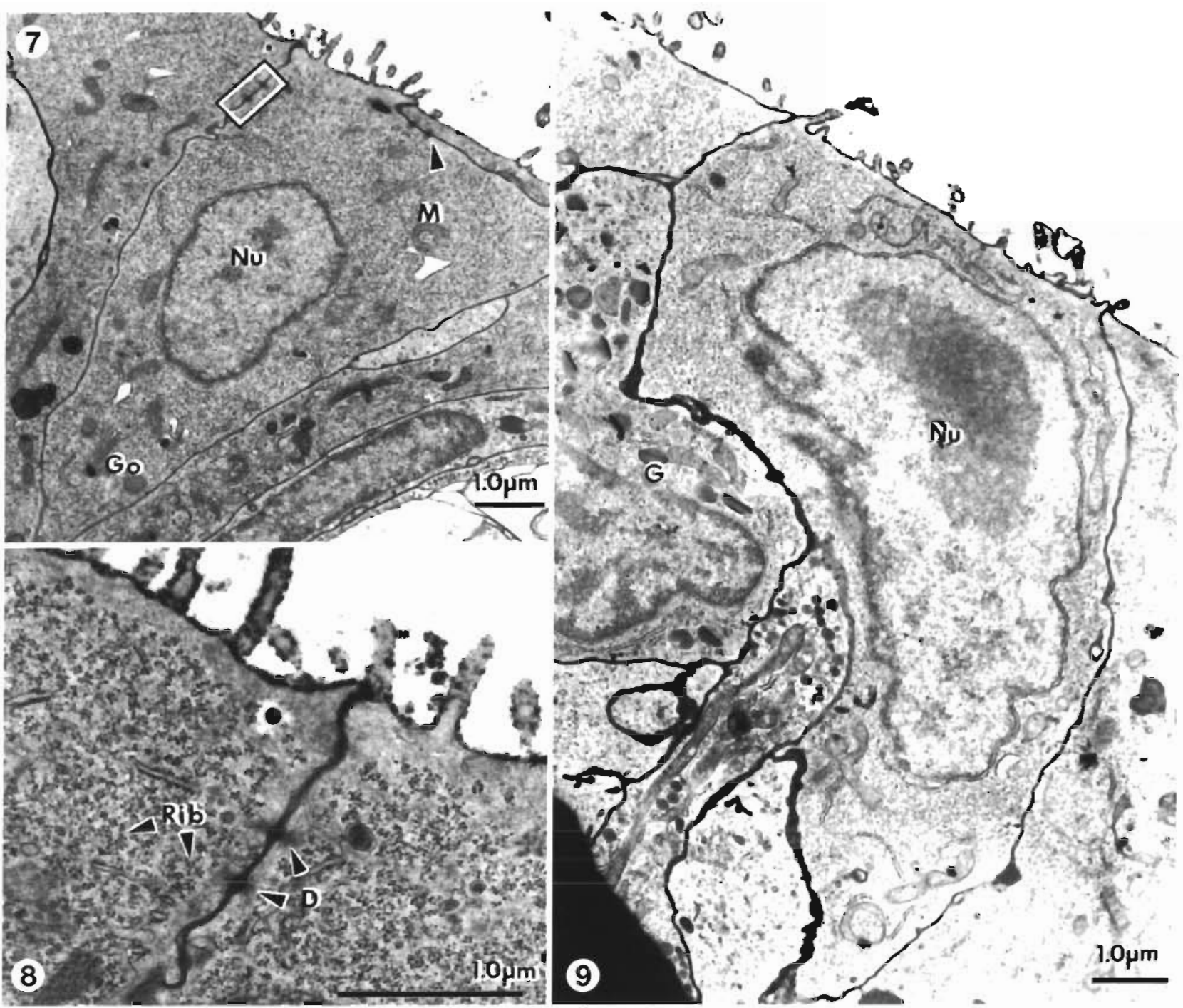
BRDU-labelled cells were observed at the median and the tip of the folds as well (Fig. 2). At this time, the carp were heavily infected with merogonic, gamogonic and sporogonic developmental stages. Severe loss of epithelial cells and atrophy of mucosal folds occurred in affected intestines. The folds were covered with a layer of squamous or cuboidal cells (Figs. 3 \& 4). Ultrastructurally, these cells exhibited characteristics of immature cells. They had few and short microvilli, a central or apically located nucleus, and, compared to enterocytes, increased numbers of ribosomes and fewer mitochondria (Figs. $4 \& 5$ ). There were tight junctions and desmosomes (Figs. 7 \& 8). These cells formed an irregular cover over the mucosal folds and also became infected with coccidia (Figs. 4 \& 5). Lymphoid cells and granulocytes were detected adjacent to heavily infected epithelium cells (Figs. 5 \& 9). Granulocytes apparently penetrated the basal membrane (Fig. 5).

With further development of the parasite and excretion of oocysts, on Days 13 to 18 PE, the parasite load of infected carp decreased. The architecture of the mucosal folds and structure of the mucosal epithelium regenerated and the mitotic rate of the enterocytes declined to the level of the uninfected controls.

\section{DISCUSSION}

Goussia carpelli induced increased epithelial cell turnover in intestinal tissue of infected carp. In studies on mammalian and avian hosts, increased proliferation of epithelial cells was observed with infections with various enteric protozoa (for review see Buret et al. 1990). In mammals, enterocytes arise from stem cells near the base of the crypts of Lieberkühn. An increased rate of enterocyte proliferation results in the elongation of crypts, observed, for example, in lambs infected with Eimeria spp. (Gregory et al. 1987). Compared to mammals, the intestine of carp has a simple architecture. The mucosa forms slender folds covered by an epithelium of columnar enterocytes which arise from stem cells near the base of folds (Iwai 1969, Noaillac-Depeyre \& Gas 1976). At this location we observed an increase in the number of mitotic cells in the intestine of G. carpelli-infected carp as early as $4 \mathrm{~d}$ PE. Previously, epithelial hyperplasia was considered a response to epithelial damage, cell loss and villus atrophy. However, in some cases it preceded villus atrophy (Gregory 1990). In our experiments, elevated numbers of mitotic epithelial cells were seen in the intestine of infected carp on Day $4 \mathrm{PE}$, before any tissue damage occurred. In vitro findings on small intestine organ explants demonstrated that crypt cell proliferation can be initiated by $\mathrm{T}$-cell activation in the absence of damage to surface enterocytes (Cunha
Ferreira et al. 1990). In the avian intestine, intraepithelial lymphocytes mainly represent $T$ cells, and in avian coccidiosis $T$ cell-parasite interactions are crucial for elimination of coccidia (Lillehoj \& Trout 1994). In carp intestine, numerous intraepithelial lymphocytes occur (Rombout et al. 1989); most of these cells reacted with a monoclonal antibody specific for carp T cells (Rombout et al. 1998). It remains to be determined whether these cells are activated during the infection of carp with $G$. carpelli and might induce the increased proliferation of enterocytes which was observed in parasitized carp.

The increased rate of cell turnover in carp with acute coccidiosis suggests that immature epithelial cells spread along the surface of the mucosal folds. These cells had a squamous to cuboidal shape, nuclear apolarity, and very few microvilli. Their epithelial origin was confirmed by the presence of tight junctions and desmosomes with adjacent cells (Pabst 1987). Corresponding to their observed immature structure, these cells are probably physiologically immature (Buret et al. 1990), which impairs their absorptive functions. In mammalian coccidiosis this can cause diarrhea (Gregory 1990). Because carp live in an aquatic environment, diarrhea and subsequent dehydration is less serious then for terrestrial animals. Instead, such fishes are threatened by an influx of water, which enters across all permeable surfaces such as gill lamellae, and oral and intestinal mucosa (Wendelaar Bonga 1993) causing hydration of the body fluids. Dilution of blood plasma was observed in carp during the acute phase of an infection with Goussia carpelli (Steinhagen et al. 1997). The effect that impaired absorption of immature enterocytes has on carp physiology is unknown.

In heavily affected intestinal segments, Goussia carpelli infected all enterocytes of mucosal folds from tip to base. From tissues sampled on consecutive days, we concluded that gut segments with severely damaged epithelium and disrupted mucosal architecture had regenerated within a few days. Based on counts of mitotic figures in cells from regenerating tissues, early workers (e.g. Wunder \& Schimke 1935) concluded that injured fish tissues had a high regenerative capacity. In the present study, we labeled dividing cells by means of BRDU-uptake and visualized the number and the distribution of proliferating cells in regenerating piscine tissues. Using this method, we showed that in carp intestine the regenerative process originated from cells at the base of the mucosal folds. Futhermore, the high regenerative capacity of the carp intestine could be confirmed. This might be responsible for the low pathogenicity of coccidiosis in carp. In our laboratory experiments, no carp died from the infection; all recovered. 
Acknowledgements. This study was financially supported by a grant from the Deutsche Forschungsgemeinschaft. Mr S. H Leenstra and Dr G. Wiegertjes, Wageningen, The Netherlands, kindly provided fertilized carp eggs. Many thanks to Mrs K. Rohn and K. Franke, Hannover, who gave excellent technical support.

\section{LITERATURE CITED}

Buret A, Gall DG, Nation PN, Olson ME (1990) Intestinal protozoa and epithelial cell kinetics, structure and function. Parasitol Today 6:375-380

Cunha Ferreira R, Forsyth LE, Richman PI, Wellis C, Spencer J, MacDonald TT (1990) Changes in the rate of crypt epithelial cell proliferation and mucosal morphology induced by a $T$ cell-mediated response in human small intestine. Gastroenterology 98:1255-1263

Davies AJ, Ball SJ (1993) The biology of fish coccidia. Adv Parasitol 32:293-366

Gregory MW (1990) Pathology of coccidial infections. In T.ong PL (ed) Coccidiosis of man and domestic animals CRC Press, Boca Raton, FL, p 235-261

Gregory MW, Catchpole J, Norton CC, Pittilo RM (1987) Synchronized division of coccidia and their host cells in the ovine intestine. Parasitology Res 73:384-386

Iwai I (1969) Fine structure of gut epithelial cells of larval and juvenile carp during absorption of fat and protein. Arch Histol Jpn 30:183-199

Jendrysek S, Steinhagen D, Drommer W, Körting W (1994) Carp coccidiosis: intestinal histo- and cytopathology under Goussia carpelli infection. Dis Aquat Org 20:171-182

Kent ML, Hedrick RP (1985) The biology and associated pathology of Goussia carpelli (Leger and Stankovitch) in goldfish Carassius auratus (Linnaeus). Fish Pathol 20 $485-494$

Lillehoj HS, Trout JM (1994) $\mathrm{CD}^{+} \mathrm{T}$ cell-coccidia interactions. Parasitol Today 10:10-14

Lom J, Dyková I (1992) Protozoan parasites of fishes. Developments in aquaculture and fisheries science 26. Elsevier Amsterdam
Lom J, Steinhagen D, Körting W, Dyková I (1991) Oocyst formation in the coccidian parasite Goussia carpelli. Dis Aquat Org 10:203-209

Noaillac-Depeyre J, Gas N (1973) Absorption of protein macromolecules by the enterocytes of the carp (Cyprinus carpio L.J. Z Zellforsch 146.525-541

Pabst R (1987) The anatomucal basis for the immune function of the gut. Anat Embryol 176:135-144

Rombout JHWM, Bot HE, Taverne-Thiele JJ (1989) Immunological importance of the second gut segment of carp. II Characterization of mucosal leucocytes. I Fish Biol 35: $167-178$

Rombout JHWM, Joosten EHM, Engelsma MY, Vos AP, Taverne N, Taverne-Thiele JJ (1998) Indications for a distinct putative $T$ cell population in mucosal tissues of carp. Dev Comp Immunol 22:63-77

Romeis B (1968) Mikroskopische Technik, 16th edn. Oldenbourg Verlag. München

Schäperclaus W (1979) Fischkrankheiten, 4th edn. Akademie Verlag, Berlin

Schutte B, Reynders MM, Bosman FT, Blijham GH (1987) Studies with anti-bromodeoxyuridine antibodies: II. Simultaneous immunocytochemical detection of antigen expression and DNA synthesis by in vivo labelling of mouse intestinal mucosa. J Histochem Cytochem 35:371-374

Steinhagen D (1991) Ultrastructural observations on merogonic and gamogonic stages of Goussia carpelli (Apicomplexa, Coccidia) in experimentally infected common carp Cyprinus carpio. Eur J Protistol 27:71-78

Steinhagen D, Körting $W(1990)$ The role of tubificid oligochaetes in the transmission of Goussia carpelli. J Parasitol 76:104-107

Steinhagen D. Oesterreich B, Körting W (1997) Carp coccidiosis: clinical and hematological observations of carp infected with Goussia carpelli. Dis Aquat Org 30:137-143

Wendelaar Bonga SE (1993) Endocrinology. In: Evans DH (ed) The physiology of fishes. CRC Press, Boca Raton, FL, p 469-502

Wunder W, Schimke H (1935) Wundheilung und Regeneration beim Karpfen. Arch Entwicklungsmech Org (Wilhelm Roux) 133:245-268

Submitted: April 14, 1998; Accepted: June 22, 1998

Proofs received from author(s): July 27, 1998 